\title{
The Analysis Condition of Special Library for Street Children at UPTD "Kampung Anak Negeri” Institutions
}

\author{
Fitri Mutia ${ }^{1}$ \\ Library \& Information Department, \\ Faculty of Social and Political Sciences, Airlangga University
}

\begin{abstract}
The existence of special library UPTD the "Kampung Anak Negeri" became one medium that can be used to develop the potential of street children themselves a growing number from year to year. This study conducted descriptive quantitative research that aim to describe the condition of special libraries in UPTD "Kampung Anak Negeri", especially in terms of collections, facilities and infrastructure, library services and human resources (librarian). The four aspects are then compared with the standard of the special library collated by the National Library in 2011. In this study, data collection technique conducted in July 2016 using interview techniques as a primary technique performed on librarians and include interviews with street children as well as staff of Colleagues staff UPTD. Based on the data obtained can be concluded that the amount of the book collection of about 752 titles of books, collection development has not reached $5 \%$ per year, spacious room just $35 \mathrm{~m}^{2}$ and has only 2 rack collection. Services available are services in place read, circulation services and information search services, while the librarians who manage only one person with a background in library and information science education. In general, special libraries UPTD condition does not meet the standard, so this affects is not maximized to support learning process as well as in facilities that match the information needs of street children.
\end{abstract}

Keywords: special library, street children, special library collection and infrastructure, special library service and human resource, uptd "kampung anak negeri" institutions

The existence of street children in several big cities in Indonesia has become a common phenomenon due to the rapid urbanization, the urban development that offers decent work for weak economic community, even those who feel pressured by family circumstances and home environment. Sometimes reason of street children choose to live on the streets not only based on economic difficulties causes, but also street children's pleasure in enjoying the environment conditions in the streets free to do activities together with their peers.

The growing number of street children from year to year increase continually, According to Social Minister Khofifah Indar Parawansa, the number of street children in Indonesia increased by more than 100 percent compared to 2015 ( 1 million people), reaching approximately 4.1 million people (Jawapos.com, 2016). In Surabaya city, the number of street children can be seen by the table below.

${ }^{1}$ Korespondensi: Fitri Mutia. Library \& Information Department, Faculty of Social and Political Sciences, Airlangga University. Jln. Dharmawangsa dalam. Telp. +62315034015 Email: fitri.mutia75@yahoo.co.id 
Table 1. The number of street children in Surabaya

\begin{tabular}{ccc}
\hline No. & Tahun & Jumlah \\
\hline 1 & 2011 & 45 \\
2 & 2012 & 94 \\
3 & 2013 & 114 \\
\hline
\end{tabular}

Source: Social Service Surabaya, 2014

The increase in the number of spur Surabaya Social Department continuously strive to reduce the number of street children and provide guidance through UPTD "Kampung Anak Negeri", although it is only able to accommodate 35 children. The existence of the Regional Technical Implementation Unit (UPTD) "Kampung Anak Negeri" Surabaya, try to provide care for street children who are still able to give education and guidance for the success of their lives in the future. This social institutions organize various beneficial activities for street children in order to avoid the emergence of broader social problems, such as mental and spiritual guidance, guidance of physical, social, interests and talents, skills, including cognitive guidance which organized by implementing educational programs (informal). One of the media that is used to develop their cognitive abilities is through a special library provided by UPTD. Special library is a library which is applied on a limited basis for user within government institutions, community agencies, religious educational institutions, houses of worship, or other organization (UU / 43/2007).

The library can be exploited to develop the potential of street children in UPTD "Kampung Anak Negeri" so that they can equip themselves with the knowledge that is useful as a preparation for life in the era of the information society. Thus, the library as a learning tool is expected to be a force for the nation, especially for street children who now live in the information age, libraries are very instrumental in providing information quickly and accurately.

\section{Method}

This research is descriptive quantitative research aimed to investigate the circumstances, conditions or other things (circumstances, conditions, circumstances, events, activities) that the results presented in the form of research reports (Arikunto, 2010). Researchers describe the condition of special libraries in UPTD 'Kampung Anak Negeri ", especially in terms of collections, facilities and infrastructure, library services and human resources (librarian). The four aspects are then compared with the standard of the special library collated by the National Library in 2011.

Collecting data in this study conducted in July 2016 using interview techniques as a primary technique performed on librarians (numbered 1), and include data from interviews with street children and staff UPTD. Besides these techniques, the data were also obtained through observation of the condition of the library researcher UPTD the "Kampung Anak Negeri". 


\section{Result}

Library UPTD the "Kampung Anak Negeri" which is located at Highway wonokromo

No. 130 Rungkut, is a special library which was established by SK Perwali No. 61 in 2012.This library helps street children to meet the needs of reading material and also improve the quality of their mental and moral intelligence. Some of them had initially not been able to write and read at all, but with the help from librarian now they can read even create a resume from a book and also stimulate children love to read.

Vision library UPTD the "Kampung Anak Negeri" is to bring children into behaving socially problematic normative and independent so that they can perform their social function adequately in society. The mission is run is to raise awareness to develop the potential of children with social problem as well as facilitating the growth of motivation and business community in handling children with social problem.

User in this library are street children in UPTD "Kampung Anak Negeri" Surabaya entirely (15 children) male, their age range 12-14 years and education levels are generally at the junior level as many as 10 people (66.7\%). In addition, the colleagues staff also be user in UPTD library that totaled 15 people $(88.2 \%)$ were male, $2(11.8 \%)$ women and aged around 26-30 years $(41.2 \%)$.

Based on observations and interviews in UPTD 'Kampung Anak Negeri" Surabaya, obtained the following data:

\section{UPTD "Kampung Anak Negeri" Surabaya Special Library Collection}

A collection as library materials is very important to improve the knowledge of street children and useful to complete the task of formal schooling. Materials in the collection UPTD just a collection of materials printed, printed material collection consists of a collection of books of various fields ranging reading for adults, adolescents and children. Table 2 below shows the collections UPTD 2015 by order of the classes.

Table 2. UPTD Special Library Collections (2015)

\begin{tabular}{cccl}
\hline Kelas & $\begin{array}{c}\text { Jumlah } \\
\text { Judul }\end{array}$ & $\begin{array}{c}\text { Jumlah } \\
\text { Eksemplar }\end{array}$ & Deskripsi \\
\hline 000 & 35 & 50 & Karya Umum, Ilmu \\
& & & Komputer dan Informasi \\
100 & 30 & 48 & Filsafat \& Psikologi \\
200 & 39 & 50 & Agama \\
300 & 148 & 220 & Ilmu-Ilmu Sosial \\
400 & 40 & 40 & Bahasa \\
500 & 61 & 91 & Sains \& Matematika \\
600 & 131 & 208 & Teknologi \\
700 & 88 & 147 & Kesenian \& Rekreasi \\
800 & 149 & 198 & Sastra \\
900 & 31 & 63 & Sejarah \& Geografi \\
\hline
\end{tabular}

The laying of the collection on the shelf just based on fields of school subjects. Care is also very standard collection that is only in the wash as needed. The collections in UPTD obtained from the Social Department Surabaya aid and donations from the community or 
students who do visit or research to the location. This UPTD library material gain new collection every two months. Material collections are usually arranged in two racks available, but because of the bookshelf in the library is full, then some other books arranged in a box to keep easy to access by street children in this UPTD special library.

Through the following picture can be seen in the collection rack UPTD conditions "Kampung Anak Negeri".

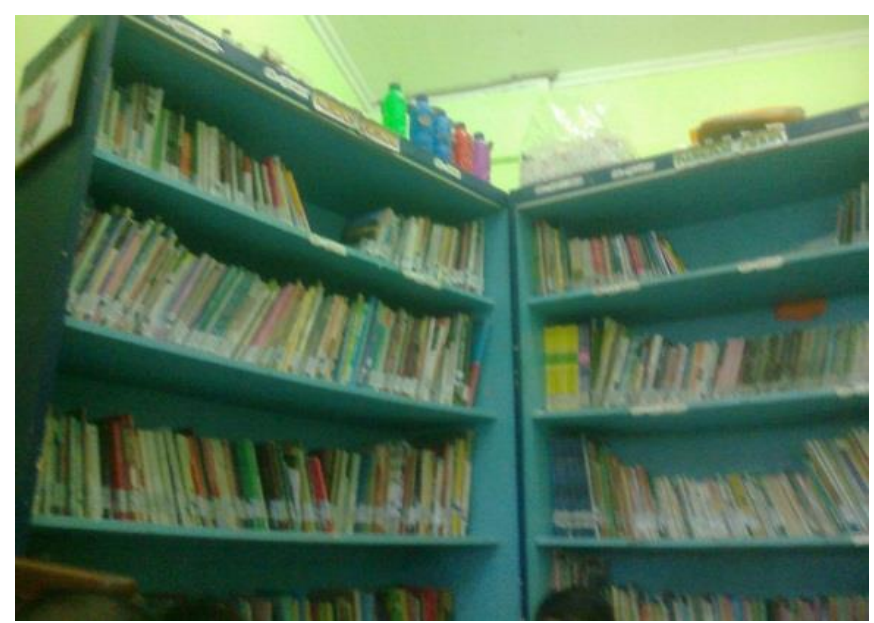

Figure 1. Arrangement of the Collection on the Shelves

Type in the library collection includes books in table 2 are provided to help street children in the search for an information and develop their reading habits. Picture below shows a collection that is still left in the box because it does not fit anymore when in place on the rack collection.

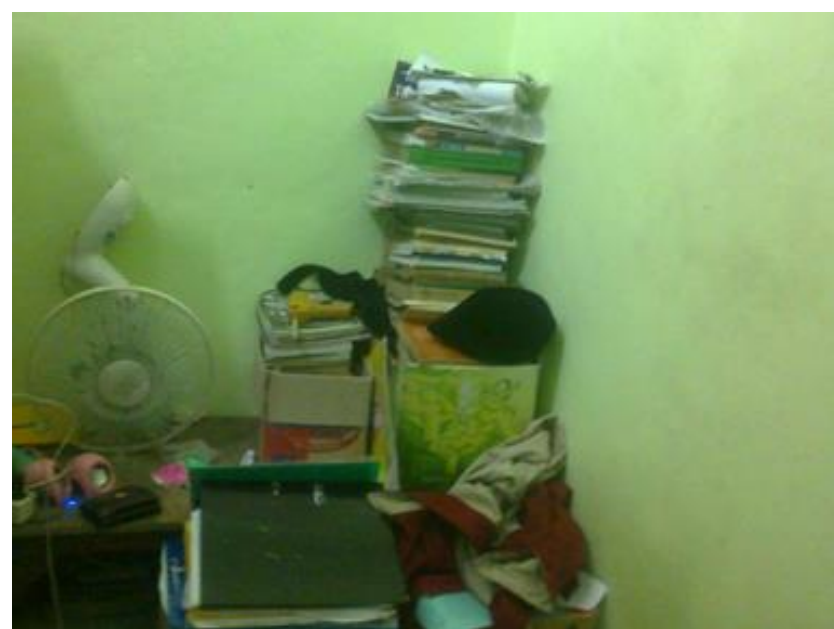

Figure 2. Book Collection Placed in Cartons Box 


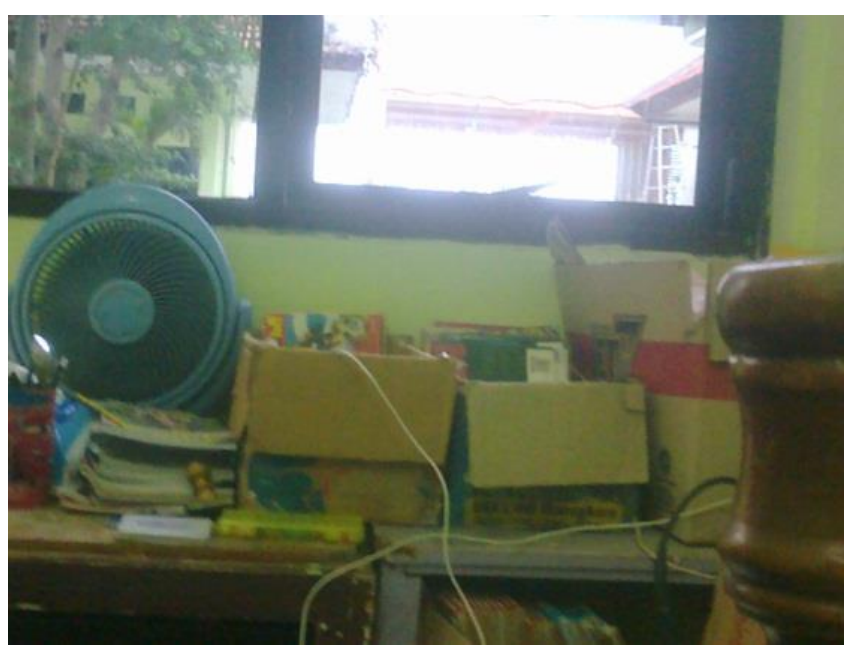

Figure 3. Book Collection Placed in Cartons Box

Conditions seem inadequate shelf to load the entire collection is owned by UPTD, therefore librarians chose to organize another collection in a box.

Based on interviews conducted to street children in UPTD, we knows that kind of information that frequently accessed by the street children are mostly related to hobbies (such as music, sports) by 9 people $(60.0 \%)$, while information regarding the school work as much as 4 people or by $26.7 \%$.

\section{Infrastructures in UPTD "Kampung Anak Negeri" Surabaya Special Library}

UPTD library is in the same area with UPTD the "Kampung Anak Negeri", while the building area of about $35 \mathrm{~m}^{2}$, due to the limited area of the room, then the room library consists of only one room for reading room at the same place for the collection. In the room provided a bookshelf ( 2 pieces), desks ( 1 piece), but has not provided a magazine rack, a table read, reading chair, and computer device.

Forms of information channels that are frequently accessed by street children as many as 6 people $(40.0 \%)$ stated they access information by borrowing books at the library, then each of those 4 people $(26.7 \%)$ accessing information through the internet and asked the colleagues staff. Thus, the information channels that are frequently accessed by street children in UPTD "Kampung Anak Negeri" is the library, because street children are not given access to the internet and colleagues staff suggest them to look in the library, and if they need information on the internet usually the colleagues staff who will find the information for them. The following phrase information from respondents:

"Sebenere pengen nang internet, tapi nak kene gak enek komputer gak enek hape gae internetan mas, lek butuh internetan biasane nang pembina, dadie lek pengen moco yo nang perpustakaan iki." (R.14)

UPTD library does not provide computer media, because it is often used by children to play games, lead to addicted playing game. If there are children who want to learn the computer, they can join the training in Surabaya Broadband Learning Centre (BLC) which is a program of the Office of Communications and Information Surabaya in Central village Wonorejo, although children may join the training who already at grade 4th. 


\section{Special Library Service}

At the beginning of the establishment of the library, hours of service begins at 13:00 until 16:00 pm, but now as long as the librarian stay at the library means it remain open until late evening. This library provides a variety of services such as reading services, circulation services and information search services, besides that, but also services performed at periodically like storytelling, books resume and drama. The street children in UPTD "Kampung Anak Negeri" not only spend time reading a book in this library, but watching a movie from librarian gadget, and also do some school projects which guided by librarians.

Street children obtaining information while in UPTD "Kampung Anak Negeri" Surabaya by asked the librarian, like statements from the following respondents:

"Jam 3 sore sudah selesai belajarnya, kadang saya seringnya tanya ke Mas Adit sampai jam 9 malam, diajarin juga belajarnya“. (R.15)

Figure 3 below shows the read service activities that obtained street children in place of the special library UPTD.

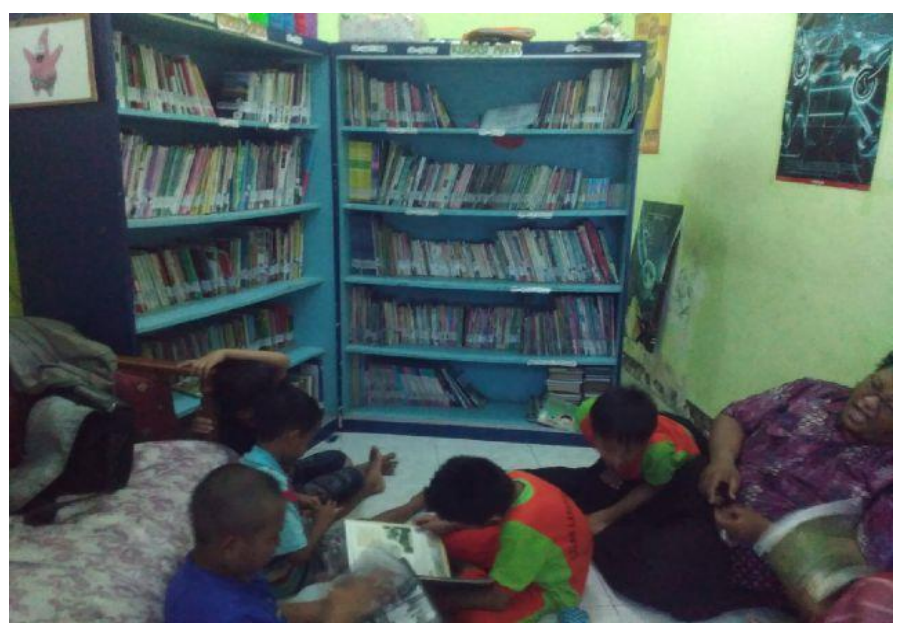

Figure 4. Street Children at the Library

The street children in UPTD the "Kampung Anak Negeri" was also taught to make creative handicrafts with the materials that have been provided by the UPTD to fill their leisure time. The image below (fig.4) are some result of their creativity like make a picture story using paper. They also taught the imagination about boat design by using artificial paper money that displayed in a frame made from carton box so that it becomes a unique decoration. 


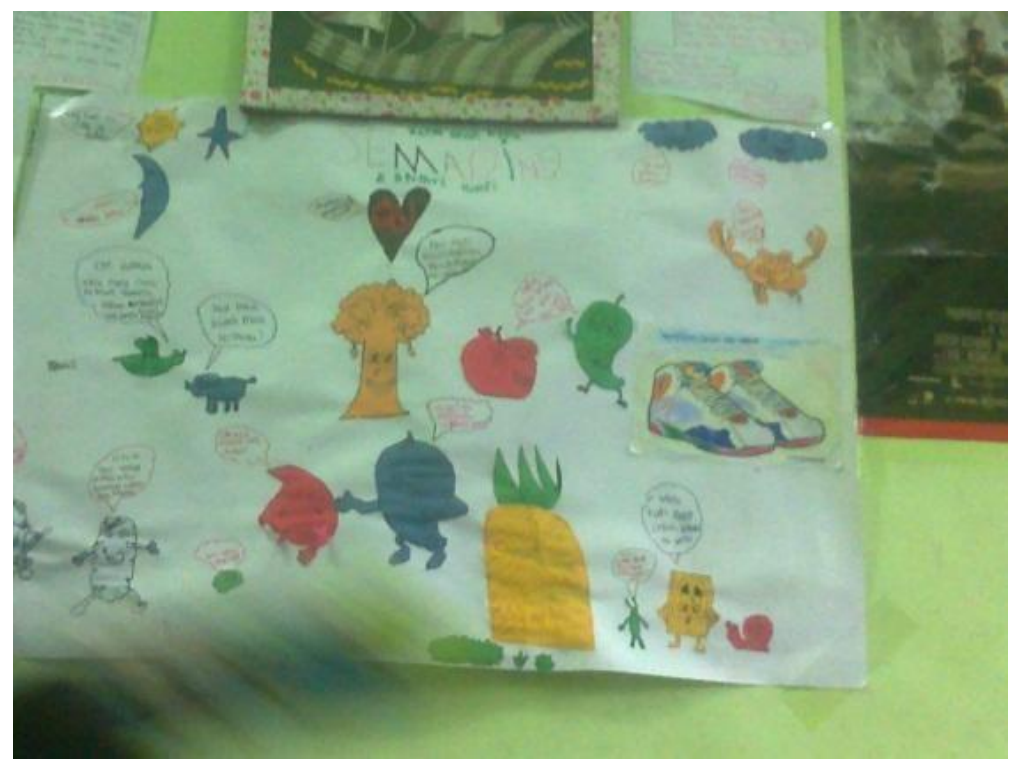

Figure 5. Children at UPTD "Kampung Anak Negeri" Creativity

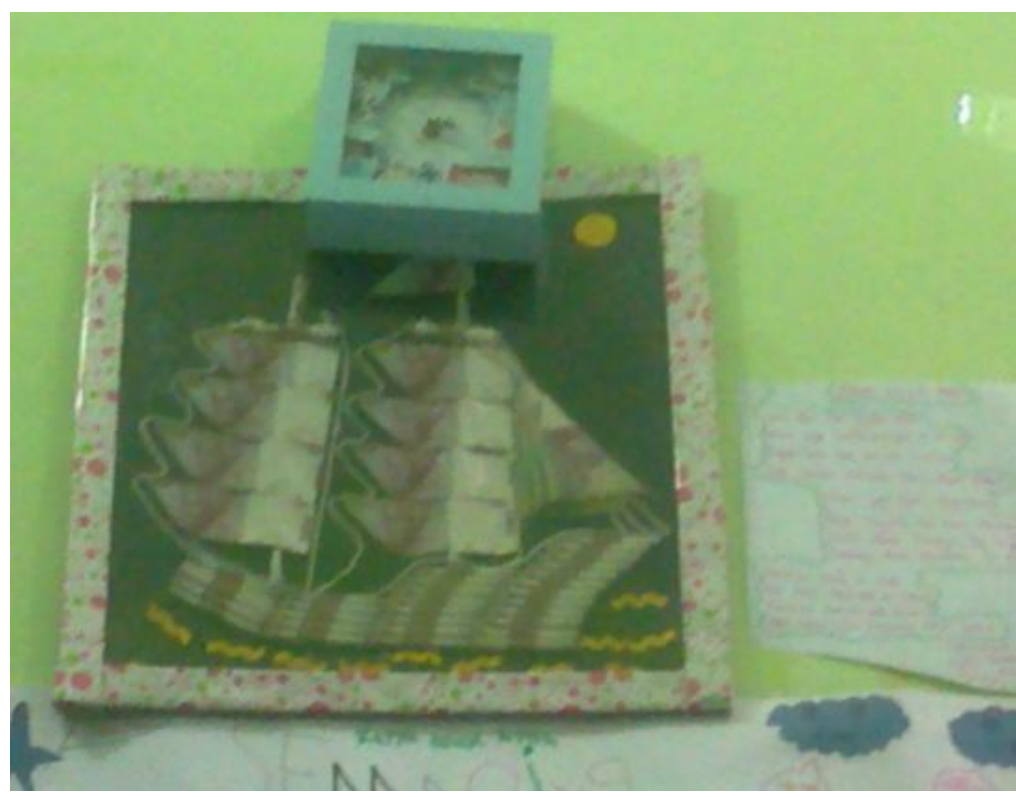

Figure 6. Children at UPTD "Kampung Anak Negeri" Creativity

\section{Human Resources}

The librarian who managed UPTD special library was only one person with an education background undergraduate from information and library science. To improve his competence, on certain occasions librarians participating in education and training activities in librarianship which was held by the library of the Surabaya city.

In fact, the librarian became one of the co-work of the colleagues UPTD staff in developing strategies to help street children in obtaining information needed. A total of 13 colleagues staff $(76.5 \%)$ to develop coordination with another colleagues to help street children in meeting the information, while two colleagues $(11.8 \%)$ in coordination with the library staff to provide information according to the needs of street children and 2 others colleagues $(11.8 \%)$ seeks to find own information needed by street children. 
When a street child is experiencing difficulty finding information, they will asked to colleagues or to a librarian, and they will directly help the children to find the information needed, such as what street children say:

"Lek pas gak ketemu golek informasi, biasane takon nang pembina mas jaok bantuan, lek gak ngunu nang mas adit (pustakawan), tanya mas iki eneg tugas sekolah aku butuh bantuan mas ngerjakno ambi golekno bukune" (R. 9)

Based on the description above, to determine whether the conditions of the special library UPTD "Kampung Anak Negeri" especially aspects of the collection, infrastructure, services and human resources have met the criteria as special libraries in accordance with the standards, then the condition compared with SNP 006: 2011, The results can be seen in table 3 below.

Table 3. The Conditions of Special Libraries UPTD “Kampung Anak Negeri Surabaya Compare with SNP 006: 201

\begin{tabular}{cc}
\hline No & \multicolumn{1}{c}{ Aspek SNP 006:2011 } \\
\hline 1 & \multicolumn{1}{c}{ Aspek Koleksi } \\
& • Jumlah Koleksi sekurang-kurangnya: \\
& koleksi buku (500 judul), referensi (100 \\
& judul), koleksi khusus (50 judul), literature \\
& kelabu (20 judul), koleksi audio visual (5 \\
& judul)
\end{tabular}

- Jenis koleksi buku meliputi koleksi khusus, koleksi deposit, terbitan berkala, refrensi, literature kelabu, audio visual

- Pengembangan koleksi sekurangkurangnya 5\% dari jumlah judul pertahun.

- Cacah ulang/penyiangan koleksi setiap 3 tahun sekali

- Melakukan perawatan koleksi, penjilidan dan perbaikan koleksi yang rusak

- Luas bangunan sekurang-kurangnya 200 $\mathrm{m}^{2}$

- Lokasi terletak dalam satu gedung dengan lembaga induk Kondisi di perpus UPTD Anak Negeri Aspek Koleksi

○ Jumlah koleksi buku (sekitar 752 judul buku), koleksi referensi masih terbatas hanya ada kamus kurang lebih 3 judul, belum ada koleksi khusus dan literature kelabu, dan belum memiliki koleksi audio visual (apabila nonton film hanya lewat laptop milik pustakawan)

- Memiliki koleksi referensi, dan terbitan berkala (majalah)

- Pengembangan koleksi belum mencapai $5 \%$ setiap tahun karena pengembangan koleksi dilakukan sesuai dengan kondisi keuangan. Apabila ada penambahan koleksi biasanya hibah buku paket siswa dari badan arsip dan perpustakaan serta hibah dari masyarakat

- Belum pernah dilakukan penyiangan/cacah ulang, karena keterbasan SDM

- Perawatan masih dilakukan secara sederhana, seperti jika ada yang sobek di perbaiki, namun jika sudah rusak parah tidak dilakukan perbaikan.

Aspek Sarana dan Prasarana

- Luas bangunan $35 \mathrm{~m}^{2}$, dengan lebar ruangan $3,5 \mathrm{~m}$ dan panjang $10 \mathrm{~m}$

- Lokasi perpustakaan terletak satu gedung dengan lembaga UPTD "Kampung Anak Negeri" 
- Ruangan perpus, terdiri dari ruang koleksi, ruang baca dan ruang serba guna.

- Sar-pras: rak buku (4 buah), rak majalah (1 buah), meja baca (10 buah), meja kerja ( 2 buah), kursi baca (15 buah), perangkat komputer (2 unit)

\section{Aspek layanan}

- Jam buka perpus, minimal 7 jam per hari

- Layanan terdiri dari: layanan baca di tempat, sirkulasi, refrensi, penelusuran informasi, bimbingan pustaka

- Melakukan kerjasama dengan unit kerja/instansi bersangkutan Aspek SDM

- Memiliki tenaga sekurang-kurangnya 3 orang (1 pustakawan, 2 orang teknisi)

- Kualifikasi Pimpinan perpustakaan minimal pendidikan D2 perpustakaan / diklat perpustakaan

- Kualifikasi tenaga pengelola perpus minimal SLTA

- Melakukan pembinaan tenaga perpustakaan melalui diklat perpustakaan
- Ruangan perpus terdiri dari ruang baca yang bersatu dengan ruang koleksi, karena keterbatasan tempat

- Tersedia rak buku (2 buah), meja kerja (1 buah), namun belum ada rak majalah, meja baca, kursi baca, dan perangkat komputer

Aspek layanan

○ Jam buka sudah memenuhi minimal 7 jam perhari. Karena perpustakaan selalu terbuka untuk anak jalanan selama masih ada pustakawannya.

- Layanan terdiri dari layanan baca ditempat, layanan sirkulasi dan layanan penelusuran informasi

- Sudah melakukan kerjasama dengan perpustakaan kota Surabaya

Aspek SDM

- Hanya memiliki 1 orang pustakawan

- Kualifikasi pimpinan sekaliguas pustakawan yaitu sarjana ilmu informasi perpustakaan

- Pustakawan mengikuti diklat kepustakawanan dari perpustakaan kota Surabaya.

In addition to the condition of the library, in this study is also known that one of the street children in this UPTD not want to go to school because of boredom despite being advised by the teachers and the staff at UPTD companion. He was addicted to online games so lazy and bored to go to school when in fact he has a pretty smart thinking. Interest highly in reading because within a week he was able to spend a very thick novel, and of pleasure reading the novel he finally tried to write a novel with the detective genre that interested him. The writing skills of street children in the appreciation by the education department of Surabaya which motivated her to write a novel and will be booked, so although not in school, he still has activities to fill the time everyday.

\section{Conclusion}

The conditions of special library UPTD "Kampung Anak Negeri" Surabaya, have not comply with the National Library Standards (SNP) 2011. The library is more widely used for street children homework from school teachers and they usually ask librarians for helping them to complete the task. 
Basically street children in UPTD "Kampung Anak Negeri" has a very high spirit and willingness to learn in a variety of fields. These children belong to the children who are still able to be briefed on the learners and for a better life in the future.

\section{References}

Arikunto, S. (2010). Procedure Research: A practical approach. Jakarta: Rineka Reserved.

Jawapos.com. (2016). So the number of Street Children Rises 4.1 million. Retrieved from http://www.jawapos.com/read/2016/03/29/22330/jumlah-anak-jalanan-meningkatjadi-41-juta

National Library of Indonesia. (2011) National Standards Library (SNP): the field of public libraries and special libraries 